\title{
Occurrence of Clubroot on Pak-Choi Caused by Plasmodiophora brassicae
}

\author{
Wan Gyu Kim*, Mi Hwa Moon ${ }^{2}$, Jin Hee Kim', Hyo Won Choi ${ }^{1}$ and Sung Kee Hong ${ }^{1}$ \\ ${ }^{\prime}$ Agricultural Microbiology Division, National Academy of Agricultural Science, Rural Development Administration, Suwon 441-707, Korea \\ ${ }^{2}$ Gwangiu City Farming Technique Center, Gwangiu 464-720, Gyeonggido, Korea
}

(Received February 27, 2009. Accepted March 10, 2009)

Clubroot symptoms occurred severely on roots of Pak-Choi (Brassica campestris ssp. chinensis) grown in greenhouses in Gwangju city, Gyeonggi province, Korea in September, 2008. The incidence of the disease symptoms reached as high as $90 \%$ in three greenhouses investigated. The root galls collected from the greenhouses were sectioned using a scalpel and observed by light microscope. Many resting spores were found in the cells of the root gall tissues. Suspension of resting spores was prepared from the root galls and inoculated to roots of healthy Pak-Choi plants. Each of five resting spore suspensions caused clubroot symptoms on the roots, which were similar to those observed during the greenhouse survey. Resting spores of the pathogen were observed in the cells of the affected roots. The clubroot pathogen was identified as Plasmodiophora brassicae based on its morphological and pathological characteristics. This is the first report that Plasmodiophora brassicae causes clubroot of Pak-Choi.

KEYWORDS : Brassica campestris ssp. chinensis, Clubroot, Pak-Choi, Pathogenicity, Plasmodiophora brassicae

Pak-Choi (Brassica campestris L. ssp. chinensis Jusl.) is grown primarily in Asian countries and is a popular vegetable in Korea. Clubroot symptoms were observed on roots of Pak-Choi grown in greenhouses in Gwangju city, Gyeonggi province, Korea, during a disease survey per- formed in September, 2008. The symptoms appeared as galls on the roots (Fig. 1A). The infected plants were retarded in growth and wilted at the late stage of growth (Fig. 1B). Three greenhouses of Pak-Choi were investigated for disease occurrence. The incidence of the dis-
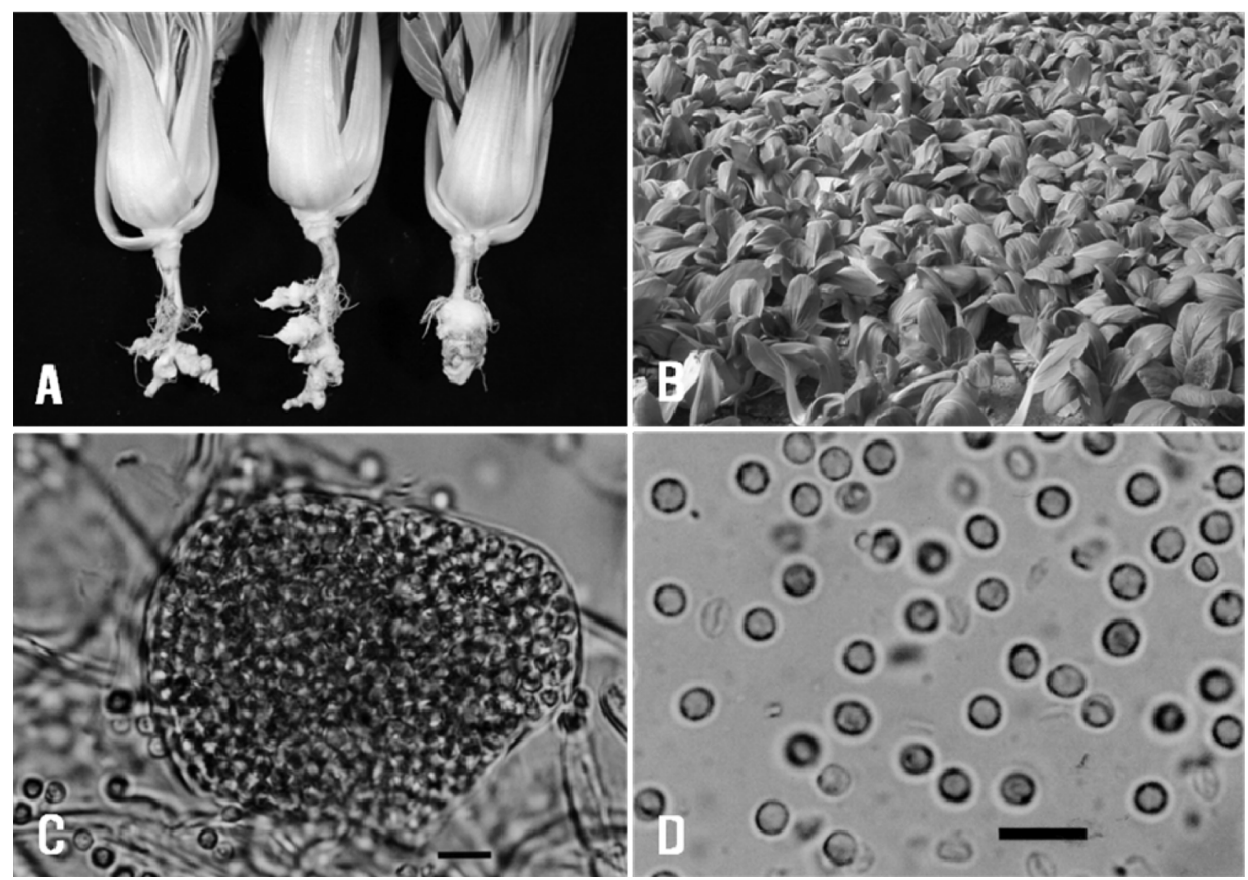

Fig. 1. Clubroot symptoms on Pak-Choi plants observed in the greenhouse and observation of root tissue sections by light microscope. A, galls produced on the roots; $\mathrm{B}$, infected plants showing wilt; $\mathrm{C}$, a cell including resting spores and resting spores released from the cell $($ scale bar $=10 \mu \mathrm{m}) ; \mathrm{D}$, resting spores released from cells (scale bar $=10 \mu \mathrm{m})$.

*Corresponding author <E-mail : wgkim@rda.go.kr> 


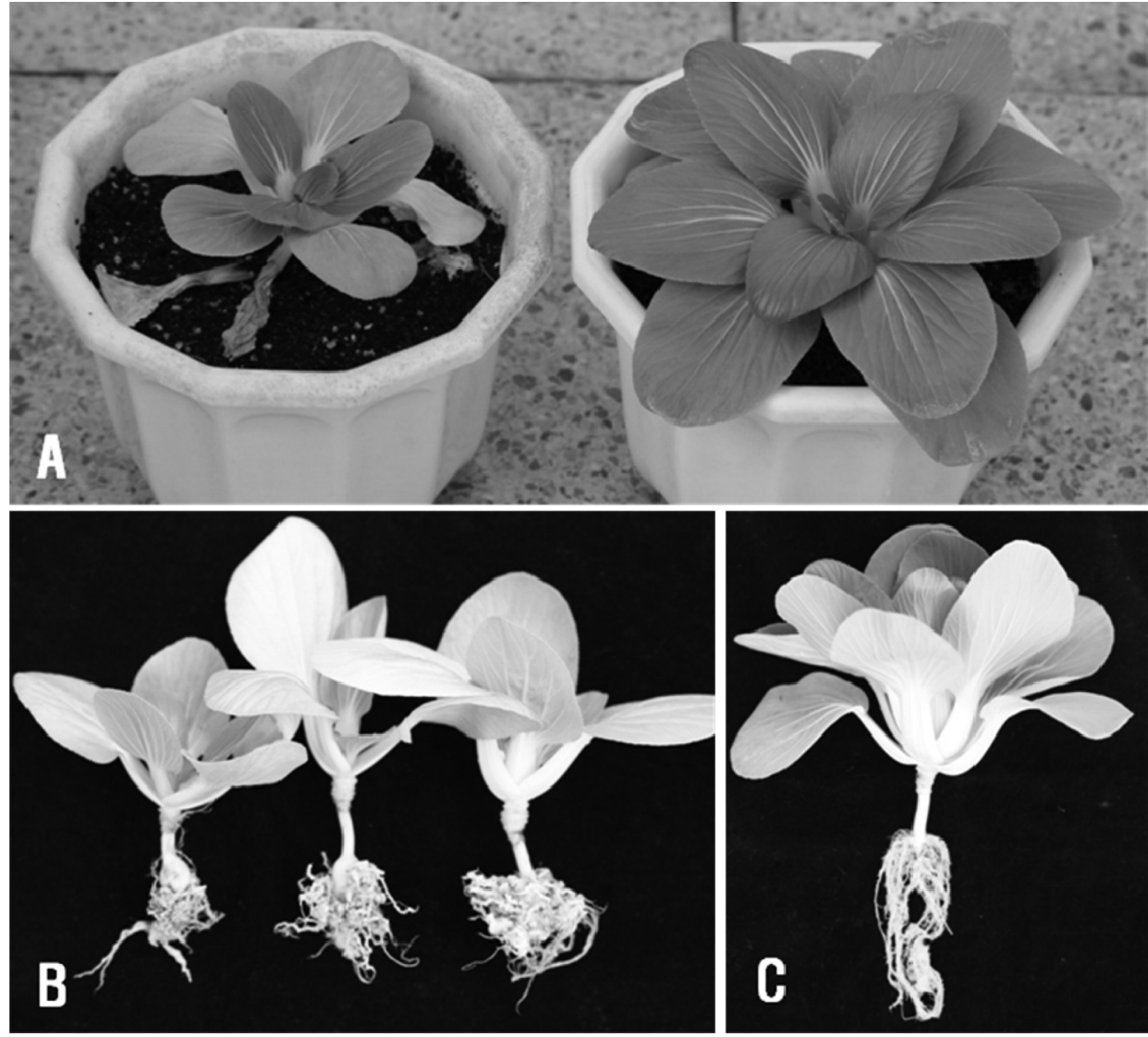

Fig. 2. Clubroot symptoms produced on healthy Pak-Choi plants 48 days after inoculation with resting spore suspensions of the pathogen. A, an inoculated plant showing growth retardation (left) and a non-inoculated plant showing normal growth (right); B, inoculated plants with root galls; C, a non-inoculated plant showing normal growth of roots.

ease symptoms ranged from 1 to $90 \%$ in the greenhouses investigated.

Root galls of Pak-Choi were collected from the greenhouses for examination and inoculation experiments. The root galls were sectioned using a scalpel and observed by light microscope. Many resting spores were found in the cells of the root gall tissues (Fig. 1C and 1D). The resting spores were hyaline, spherical and measured 2.5 $4.0 \mu \mathrm{m}$ in diameter.

Five root galls of Pak-Choi collected were used for inoculum preparation of the pathogen. Suspension of resting spores was prepared from each of the collected root galls by the procedure of Cho et al. (2003). The suspension was adjusted to a concentration of $5 \sim 6 \times 10^{6}$ spores $/ \mathrm{ml}$ using a hemocytometer. The $20 \mathrm{ml}$ suspension prepared from each gall was inoculated to roots of 30day-old Pak-Choi plants in a greenhouse at $18 \sim 28^{\circ} \mathrm{C}$, as previously described (Cho et al., 2003). The same quantity of sterile distilled water was used as the control. Disease ratings were made based on the degree of gall formation on the roots 48 days after inoculation. The inoculation test was performed in three independent replicates.
Each of five resting spore suspensions caused clubroot symptoms on the roots, which were similar to those observed during the greenhouse survey (Fig 2). Resting spores of the pathogen were observed in the cells of the affected roots. The clubroot pathogen was identified as Plasmodiophora brassicae Woronin based on its morphological and pathological characteristics, which were consistent with those described by Buczacki (1979). It was reported that $P$. brassicae causes clubroot of crucifers (Buczacki, 1979; Cubeta et al., 1998; Linnasalmi and Toiviainen, 1991). The disease has been a major problem in areas where Chinese cabbage and some other cruciferous crops are cultivated in Korea (Cho et al., 2003; Kim and Oh, 1997). Pak-Choi is a cruciferous crop and cultivated commonly in Asian countries. However, there has been no report on the disease occurrence in the crop. This is the first report that $P$. brassicae causes clubroot of PakChoi.

Diverse physiologic races based on the pathogenicity of P. brassicae isolates have been reported attacking crucifers (Ayers, 1957; Buczacki et al., 1975; Johnston, 1968; Williams, 1966). Further study is needed to identify races of the pathogen attacking Pak-Choi. 


\section{References}

Ayers, G. W. 1957. Races of Plasmodiophora brassicae. Can. J. Bot. 35:923-932.

Buczacki, S. T. 1979. Plasmodiophora brassicae. CMI Descriptions of Pathogenic Fungi and Bacteria. No. 621.

Buczacki, S. T., Toxopeus, H., Mattusch, P., Johnston, T. D., Dixon, G. R. and Hobolth, L. A. 1975. Study of physiologic specialization in Plasmodiophora brassicae: Proposals for attempted rationalization through an international approach. Trans. Br. Mycol. Soc. 65:295-303.

Cho, W. D., Kim, W. G. and Takahashi, K. 2003. Occurrence of clubroot in cruciferous vegetable crops and races of the pathogen in Korea. Plant Pathol. J. 19:64-68.

Cubeta, M. A., Cody, B. R. and Williams, P. H. 1998. First report of Plasmodiophora brassicae on cabbage in Eastern North Carolina. Plant Dis. 82:129.

Johnston, T. D. 1968. Clubroot in Brassicae: A standard inoculation technique and the specification of races. Plant Pathol. 17:184-187.

Kim, D. W. and Oh, J. H. 1997. Incidence, pathogenicity of clubroot fungus (Plasmodiophora brassicae) and varietal resistance in Chinese cabbage. Korean J. Plant Pathol. 13:95-99.

Linnasalmi, A. and Toiviainen, A. 1991. Occurrence of clubroot and Plasmodiophora brassicae Wor. races in Finland. J. Agric. Sci. Finland 63:415-434.

Williams, P. H. 1966. A system for the determination of races of Plasmodiophora brassicae that infect cabbage and rutabaga. Phytopathology 56:624-626. 